
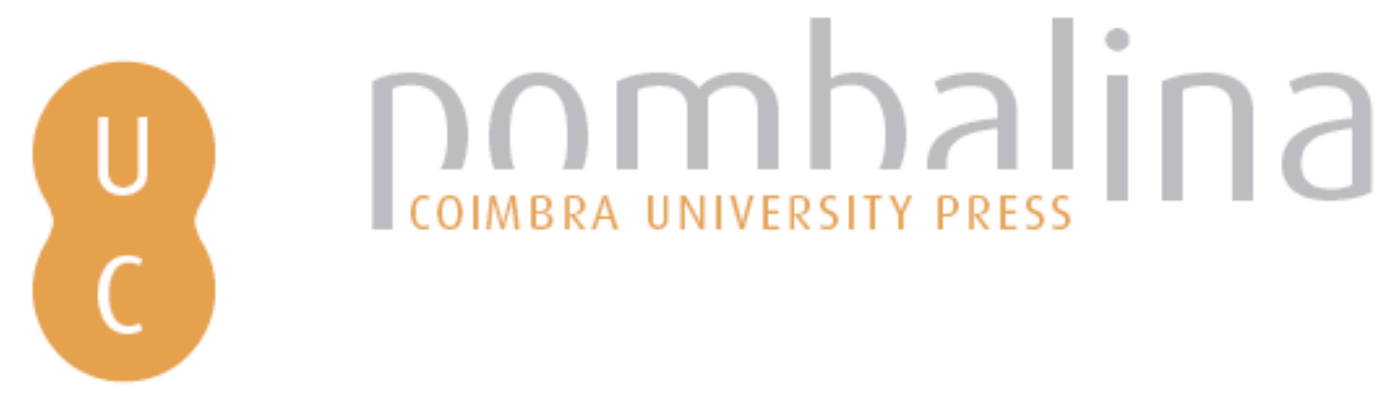

\title{
A Rússia e a Alemanha: uma relação sui generis em mudança
}

Autor(es): Daehnhardt, Patrícia

Publicado por: Imprensa da Universidade de Coimbra

URL

persistente:

URI:http://hdl.handle.net/10316.2/31909

DOI:

DOI:http://dx.doi.org/10.14195/978-989-26-0712-2_5

Accessed : $\quad$ 26-Apr-2023 14:08:12

A navegação consulta e descarregamento dos títulos inseridos nas Bibliotecas Digitais UC Digitalis, UC Pombalina e UC Impactum, pressupõem a aceitação plena e sem reservas dos Termos e Condições de Uso destas Bibliotecas Digitais, disponíveis em https://digitalis.uc.pt/pt-pt/termos.

Conforme exposto nos referidos Termos e Condições de Uso, o descarregamento de títulos de acesso restrito requer uma licença válida de autorização devendo o utilizador aceder ao(s) documento(s) a partir de um endereço de IP da instituição detentora da supramencionada licença.

Ao utilizador é apenas permitido o descarregamento para uso pessoal, pelo que o emprego do(s) título(s) descarregado(s) para outro fim, designadamente comercial, carece de autorização do respetivo autor ou editor da obra.

Na medida em que todas as obras da UC Digitalis se encontram protegidas pelo Código do Direito de Autor e Direitos Conexos e demais legislação aplicável, toda a cópia, parcial ou total, deste documento, nos casos em que é legalmente admitida, deverá conter ou fazer-se acompanhar por este aviso. 
IMPRENSA DA

UNIVERSIDADE

DE COIMBRA

COIMBRA

UNIVERSITY

PRESS

\section{A POLÍTICA EXTERNA \\ RUSSA NO ESPAÇO \\ EURO-ATLÂNTICO}

$\therefore:$

\section{Dinâmicas de cooperaçấo e}

competiçẫo num espaço alargado

PÁTRICIA DAEHNHARDT

MARIA RAQUEL FREIRE

Coordenadoras 
(Página deixada propositadamente em branco) 


\section{CAPITULO 5}

\section{A RÚSSIA E A ALEMANHA:}

\section{UMA RELAÇ ÃO SUI GENERIS EM MUDA NÇA}

Patrícia Daehnhardt

\section{Introdução}

A história da relação entre a Alemanha e a Rússia, as duas potências centrais do continente europeu, caracteriza-se por momentos de cooperação, rivalidade e tensão. No pós-Guerra Fria a Rússia deparou-se com o papel de crescente importância da Alemanha tornando-se esta essencial à Rússia como interlocutora privilegiada de Moscovo no palco europeu e transatlântico. A Rússia articula os seus interesses securitários e energéticos em cooperação com a Alemanha para reforçar a sua posição junto dos restantes atores políticos do quadro euro-atlântico já que é através de Berlim que a Rússia exerce influência na Europa. Por seu turno, a Alemanha é um elo de articulação entre a União Europeia (UE), os Estados Unidos (EUA) e a Rússia, na medida em que a forma como a Alemanha define a sua relação com a Rússia tem repercussões sobre como estes atores lidam com Moscovo e sobre a configuração do espaço euro-atlântico. Isto sugere uma relação sui generis, cujos contornos estão a ser redefinidos, na sequência da eleição de Vladimir Putin, em março de 2012, para um terceiro mandato presidencial e a crescente desilusão dos políticos alemães face ao percecionado afastamento da Rússia dos princípios que sustentam uma ordem interna democrática e pluralista e uma ordem securitária europeia de estabilidade e cooperação. Consequentemente, 
o papel que a Alemanha desempenha na política externa russa está a mudar, perante o risco de a Rússia perder o maior defensor dos seus interesses junto da UE.

Este capítulo analisa as relações bilaterais entre a Rússia e a Alemanha de uma perspetiva de convergência quanto à procura da redefinição das respectivas identidades internacionais no pós-Guerra Fria e da normalização das suas políticas externas, e de divergência quanto à inserção em contextos institucionais diferenciados e às posições daí decorrentes. As duas narrativas que informam as condutas da política externa da Rússia e da Alemanha são abordadas no início. De seguida são analisadas as opções estratégicas prosseguidas por Moscovo e Berlim. Num cenário pós-11 de setembro de 2001 e de novos desafios energéticos e enquadramentos geopolíticos, a análise recairá principalmente sobre as políticas bilaterais nos domínios da cooperação económica, política energética e política de segurança, três dimensões que sugerem uma dinâmica própria entre Berlim e Moscovo, com implicações para a UE e a Aliança Atlântica.

\section{Enquadramento histórico}

A história revela-nos que ambos os lados, têm, de uma maneira geral, optado pela cooperação e pela gestão de um relacionamento bilateral cooperativo mais do que conflituoso. Duas vezes, em 1871 e 1990, a Rússia tolerou as pretensões da Alemanha em unificar-se, contra adversidades e, no rescaldo da Primeira Guerra Mundial, a República de Weimar, constituída em 1919 e a União das Repúblicas Socialistas Soviéticas (URSS), criada em 1922, estabeleceram relações diplomáticas entre os dois novos regimes. Assinaram o Tratado de Rapallo, composto por acordos económicos e pela cooperação militar, à margem da conferência internacional de Genova, a primeira grande cimeira económica e financeira do pós-Guerra com o objetivo de reconstruir a economia europeia (Pipes, 1995, pp. 423-435). Daí que este tratado seja, para alguns, sinónimo do receio do 'espirito de Rapallo', reflexo da cooperação bilateral entre a Alemanha e a Rússia, feita à custa e com o desconhecimento das restantes potências europeias e euro-atlânticas. 
Durante a Guerra Fria, quando a Europa foi o palco preferencial da rivalidade bipolar entre os EUA e a URSS, e quando a Europa ocidental desenvolveu uma estreita relação de segurança com os EUA através da Aliança Atlântica, enquanto a Europa de leste estava subjugada ao controlo de Moscovo através do Pacto de Varsóvia, as relações entre a República Federal da Alemanha (RFA) e a URSS foram a exceção à regra. Em setembro de 1955, ambos os Estados iniciaram relações diplomáticas, ficando patente que apesar da inserção da República Democrática da Alemanha (RDA) na zona de influência soviética, a Alemanha ocidental era a parte alemã mais relevante para Moscovo porque se encontrava no centro geopolítico da Guerra Fria e porque, a entrada, um ano antes, da RFA na Organização do Tratado do Atlântico Norte (OTAN), tinha alterado os equilíbrios geopolíticos desfavoravelmente à União Soviética.

Esta relação bilateral foi reforçada em inícios da década de 1970 quando o chanceler Willy Brandt (SPD) definiu uma política de aproximação - a Ostpolitik (política a leste) - para a URSS e a Europa de leste, cujo destinatário principal foi a RDA. Durante o processo de negociação da unificação alemã, entre novembro de 1989 e julho de 1990, a União Soviética encontrou-se numa posição enfraquecida, incapaz não apenas de impedir a unificação, como de definir os contornos do futuro quadro de segurança europeu (Stent, 1999). De facto, o futuro estatuto da Alemanha unificada foi decidido pelo governo do chanceler Helmut Kohl (CDU) e pela administração norte-americana de George Bush, acabando a Alemanha, contra a oposição inicial de Moscovo, por ficar integrada nas estruturas políticas e militares da OTAN. A concordância de Moscovo aos termos do Tratado " $2+4$ " prendeu-se mais a circunstâncias de debilidade política interna na URSS e à perspetiva de contrapartidas económicas do que à aceitação da alteração profunda que a unificação alemã iria trazer ao futuro quadro estratégico europeu ao consubstanciar-se, nos anos seguintes, o alargamento da Aliança Atlântica até junto das fronteiras da ex-URSS. As posições assumidas pela União Soviética e pela RFA nas negociações revelaram-se assim como essenciais, mas diferenciadas na definição da ordem de segurança europeia no pós-Guerra Fria e ainda se refletem em posições assumidas mais de duas décadas depois (Daehnhardt, 2009). 
No pós-Guerra Fria a Rússia deparou-se com o papel de crescente importância da Alemanha tornando-se esta essencial à Rússia como interlocutora privilegiada de Moscovo no palco europeu e transatlântico (Stelzenmüller, 2009), exercendo Berlim influência junto dos líderes do Kremlin na definição da diplomacia multilateral russa para o espaço euro-atlântico, como ilustra a aproximação dos últimos anos entre a Polónia e a Rússia e o início de consultas trilaterais. Assim, a Rússia articula os seus interesses securitários e energéticos em cooperação com a Alemanha para reforçar a sua posição junto dos restantes atores políticos do quadro euro-atlântico: é através de Berlim que a Rússia exerce influência considerável na Europa. Por seu turno, a forma como a Alemanha define a sua relação com a Rússia tem repercussões diretas sobre como os Estados Unidos e a Europa lidam com a Rússia e sobre a configuração do espaço euro-atlântico já que é a Alemanha que em boa medida serve de elo de articulação entre ambos os lados.

A relação entre a Rússia e a Alemanha é, por isso, uma relação sui generis. Para a Rússia, a Alemanha é fundamental para projetar interesses russos no quadro europeu na definição da política externa russa face à UE, à OTAN e aos EUA; desde 1991, a relação bilateral com a Alemanha é uma das importantes linhas de continuidade proveitosa ao Kremlin, em dois domínios: primeiro, porque Berlim se definiu como o interlocutor privilegiado nas relações de Moscovo com a UE (Daehnhardt, 2013b) e os EUA, o que pode amortecer os efeitos de potenciais tensões; segundo, porque a relação lhe serve de trunfo a instrumentalizar na contínua política russa de divisão dos membros da Aliança Atlântica. Para a Alemanha, a estabilidade no continente europeu passa pela cooperação com a Rússia e a inclusão de preocupações securitárias da mesma (Chivvis e Rid, 2009), o que gerou um consenso na elite política alemã de que era necessário integrar a Rússia na ordem securitária europeia que se desenvolveu após 1991.36 Apesar da diplomacia alemã não ser conduzida em detrimento

36 A expressão integração refere-se aqui à inclusão, no sentido lato, da Rússia no desenvolvimento de um contexto de cooperação que garanta a estabilidade na Europa, e não no sentido da sua adesão jurídica à União Europeia ou à Aliança Atlântica como membro de pleno direito. 
da coesão ocidental do espaço euro-atlântico, a relação bilateral assumiu um grau de autonomia considerável, como se verificou durante a crise transatlântica de 2002-2003, quando Berlim e Moscovo, juntamente com a França, se opuseram à política dos EUA para o Iraque ou em 2008, quando a OTAN adiou as negociações de adesão da Geórgia e da Ucrânia, aproximando-se da postura alemã de não hostilização de Moscovo. Para além disso, existe uma relação de dependência mútua no que se refere ao relacionamento económico e energético: a Alemanha depende do gás natural russo enquanto que a Rússia depende dos investidores alemães para modernizar a sua economia. Esta dependência mútua é, contudo, amortecida pela pertença a quadros institucionais divergentes, o que principalmente no caso da Alemanha, condiciona a sua capacidade de atuação.

\section{A Rússia e a Alemanha no espaço Euro-Atlântico}

O fim da ordem bipolar na Europa projetou a Alemanha e a Rússia pós-soviética para campos diferentes. Importa, por isso, sublinhar as diferenças de percurso, de políticas e de opções estratégicas entre Moscovo e Berlim.

A política externa da Rússia pós-soviética no pós-Guerra Fria define-se por três fases: uma primeira, durante a década de 1990, marcada pela transição assim como pela continuidade, quando a Rússia com o presidente Boris Ieltsin entrou num período de desorientação na sua política externa e confrontou-se com um estatuto de grande potência desacreditado, de Estado humilhado e enfraquecido, com fronteiras instáveis e contestadas. $\mathrm{Na}$ definição da conduta externa isto pautou-se por uma indefinição da opção estratégica, que oscilou ora entre a ocidentalização, impulsionada pelo ministro dos negócios estrangeiros, Andrei Kozyrev, visando uma aproximação à Europa e aos Estados Unidos, até 1996, ora uma preferência por privilegiar uma política de grandes potências, a primazia dos interesses russos no antigo território soviético e uma reorientação para países fora do contexto euro-atlântico, caminho escolhido por Evgeny Primakov, como ministro dos negócios estrangeiros e posterior primeiro ministro, entre 1996 e 1999. 
A partir de 2000 iniciou-se a segunda fase, catalisada pela humilhação da década antecessora, quando o presidente Vladimir Putin veio a definir um percurso de acelerada recuperação do estatuto de poder de Moscovo, assente numa crescente auto-confiança possibilitada pelo crescimento económico. A Rússia reforçou o jogo geo-estratégico no espaço pós-soviético do seu chamado 'estrangeiro próximo' através de uma política pragmática, numa evidente procura de recuperação de influência para consolidar-se como grande potência. Aqui Moscovo atuou para recuperar a sua influência em organizações como a Comunidade de Estados Independentes (CEI), a Comunidade Económica Euroasiática, e a Organização do Tratado de Segurança Coletiva (OTSC) e para garantir o acesso a matérias primas e o controlo sobre as rotas de fornecimento energético, principalmente de gás natural para a Europa. A Ucrânia e a Geórgia assim como as cinco repúblicas da Ásia Central são peças fundamentais no jogo Rússia-UE e nas relações da Rússia com a OTAN. Se no final da Guerra Fria o percurso da URSS fora de retraimento do poder de Moscovo, de fora para dentro, perdendo influência na zona mais longínqua, passando pela Europa de leste e finalmente perdendo o poder sobre as antigas repúblicas da URSS, a partir de 2000 o percurso de recuperação de poder seguia a lógica inversa, de gradual recuperação de poder junto das capitais dos novos Estados soberanos da antiga URSS, onde Moscovo apoiava regimes simpatizantes e tentava frustrar apoios europeus à democratização nesses países, como aconteceu na Geórgia, Ucrânia ou Bielorrússia.

A terceira fase da política externa russa é recente, e prende-se com o retorno de Vladimir Putin ao poder, em março de 2012, como presidente da Federação Russa. Se este facto não contraria necessariamente um cenário de continuidade da política externa com uma trajetória de assertividade e projeção de poder na dimensão internacional (Kuchins e Zevelev, 2012) já conhecida dos primeiros dois mandatos presidenciais de Putin entre 2000 e 2008 e do mandato presidencial de Dmitry Medvedev entre 2008 e 2012, é possível sugerir que os próximos anos testarão a robustez do regime russo. O catalisador foi a realização de eleições legislativas em dezembro de 2011 e a eleição presidencial de março de 2012, ambas consideradas 
fraudulentas por observadores independentes, o que fortaleceu uma vaga de oposição interna que reivindica, de forma sistemática, um processo de democratização, numa escala que o regime dificilmente poderá ignorar ou reprimir a longo prazo (Carnaghan e Hale, 2012; Dmitriev e Treisman, 2012). Porque a política externa está inextricavelmente ligada à política interna, a fragilização lenta do regime afetará a condução da política externa russa implicando duas alternativas: primeiro, uma liderança russa fragilizada nos palcos internacionais, onde outros Estados poderão tirar proveito político em negociações internacionais e pressionar Moscovo a ter uma atitude mais cooperadora, por exemplo, em relação à Síria ou ao Irão. Segundo, e em contrapartida, os factores desestabilizadores internos poderão levar o regime a negar as alterações em curso, e assumir uma posição de demonstração de força no palco internacional, através do endurecimento da postura russa em negociações internacionais ou mesmo de uma ação militar no seu 'estrangeiro próximo', por exemplo. Ambos os casos refletiriam os efeitos das mudanças internas na definição de uma nova política externa. Apesar desta terceira fase ainda estar no seu início, é um cenário que merece ser incluído na análise das atuais relações russo-alemãs, e que sugere mudanças na relação sui generis: o possível fim do consenso alemão face ao posicionamento securitário da Rússia na Europa e, por implicação, uma margem de manobra decrescente da liderança russa face à sua capacidade de lidar com Berlim.

Neste contexto de mudança, a Rússia ainda não consolidou a recuperação do seu estatuto de grande potência. É membro permanente do Conselho de Segurança das Nações Unidas, uma potência nuclear, e a sexta maior economia mundial. No plano multilateral, integra um conjunto de instituições internacionais de cariz ocidental tendo aderido, em dezembro de 2011, à Organização Mundial do Comércio (OMC). Contudo, as características que definem uma grande potência no século XXI passam pela inclusão de outros elementos relevantes, como a taxa demográfica, a diversificação dos factores de produção de riqueza e crescimento económico, e o poder normativo (ou soft power) que a potência projeta internacionalmente. No caso da Rússia, estes últimos três factores não refletem uma evolução estável e fazem com que o seu estatuto de grande potência se encontre 
numa posição volátil: em primeiro lugar, a taxa demográfica russa tem vindo a registar um declínio contínuo desde meados da década de 1990 (Sievert, Zakharov e Klingholz, 2011). Em segundo lugar, a economia russa, para além de carecer de uma modernização efetiva e de se encontrar afetada pela corrupção, é pouco diversificada porque excessivamente centrada na indústria energética, nuclear e de armamento. Depende muito da exportação - para a União Europeia - de recursos naturais como o petróleo e o gás natural, uma situação que a crise económica global tornou mais evidente e onde elevadas variações de preços no mercado energético global podem ter consequências imprevisíveis para a economia russa. A crise financeira e económica global, desde 2008 e a volatilidade do preço do petróleo provocaram uma desaceleração do crescimento económico russo, agravada pela diminuição de investimento estrangeiro na Rússia. ${ }^{37}$ Em terceiro lugar, perante a incapacidade de o maior Estado do mundo conseguir assegurar a estabilidade nas suas fronteiras, a Rússia tem relações de vizinhança complexas porque potencialmente conflituosas e tem prosseguido uma política externa de criação de estruturas institucionais modeladas pelo exemplo ocidental, mas descredibilizada pela sua ingerência nos assuntos internos da maioria desses Estados. Por último, a Rússia tem pouco a oferecer em termos de poder normativo na política internacional: no contexto de soft power ela falha em exercer atração sobre outros Estados como potência-modelo a seguir. No agrupamento conhecido como BRICs, o Brasil, a Índia, e até a China exercem mais poder normativo sobre outros atores, para além de estes se estarem a tornar mais atrativos para investidores estrangeiros do que a Rússia. É perante este quadro de incerteza quanto ao estatuto de grande potência consolidado ao qual se junta a ausência de um quadro de inserção institucional multilateral efetivo, com riscos claros, que a Rússia tenta recuperar relações bilaterais com alguns Estados

37 Em 2012, quando a economia global estava desacelerada e a zona euro em recessão, a economia russa cresceu apenas 3,4 por cento em 2012 , abaixo dos 4,3 por cento em 2011, tendo a produção industrial caido no início de 2013, pela primeira vez desde 2009. Mais significativamente, o crescimento económico russo diminuiu para metade do nível da década até a crise de 2008. Ver "Russia Overview", The World Bank. Disponível em: http:// www.worldbank.org/en/country/russia/overview. Consultado em: 12 março 2013. 
europeus. A Alemanha, por razões históricas e geoestratégicas, surge aqui como uma parceira ideal.

Em contrapartida à posição da Rússia, no espaço euro-atlântico, o peso da Alemanha aumentou de forma mais consolidada desde o fim da Guerra Fria porque a Alemanha saiu reforçada do processo de negociação internacional para a sua unificação, em 1990, afirmando-se como potência central na nova política europeia. A fórmula encontrada que tolerava esta nova posição foi o duplo reforço e alargamento do quadro multilateral euro-atlântico: tornava-se necessário 'ancorar' a Alemanha ainda mais nas estruturas institucionais existentes e estabilizar as fronteiras nessa nova Europa para a dissuadir de seguir um caminho unilateral. Assim, os alargamentos institucionais da UE e da OTAN amorteceram simultaneamente o aumento da margem de manobra da Alemanha ao mesmo tempo que esta era ainda mais integrada nas estruturas institucionais. Na realidade, contudo, seria dentro das instituições europeias e transatlânticas através da continuidade das suas políticas multilateralistas que a Alemanha iria redefinir o seu estatuto de poder (Daehnhardt, 2009 e 2011a). E neste enquadramento em transformação, se a Rússia era considerada, por muitos, um desafio ao alargamento institucional, para a Alemanha, a Rússia definia-se como um parceiro a não hostilizar e onde a cooperação deveria ser o incentivo para atenuar a rivalidade estratégica com o ocidente.

O novo contexto europeu após o fim da Guerra Fria levantou por isso para alguns países vizinhos e aliados da Alemanha não apenas o receio de que uma Alemanha unificada e fortalecida poderia constituir-se como potência hegemónica na Europa como o de que a Alemanha pudesse voltar-se para a Rússia, ou seja, iniciar um relacionamento bilateral especial com Moscovo em detrimento das suas relações com outros Estados, principalmente os da Europa de leste, que estavam agora a libertar-se da hegemonia soviética e a 'regressar à Europa'. Estes receios, contudo, revelaram-se infundados, por um lado, porque a Alemanha não ambicionava uma posição de hegemonia que pusesse em risco a integração europeia ou a comunidade de segurança criada pela Aliança Atlântica; e por outro lado, porque apesar da especificidade do relacionamento russo-alemão, este não era prosseguido à custa do capital político euro-atlântico e 
transatlântico que a Alemanha ajudou a construir desde o fim da II Guerra Mundial. A prioridade da diplomacia alemã continuava a definir-se pela sua política europeia de inserção nas estruturas comunitárias da UE através de um multilateralismo institucionalizado, e pela sua pertença à Aliança Atlântica. Apesar das transformações que a diplomacia alemã percorreu nas últimas duas décadas (Bulmer, Jeffery e Padgett, 2010), esta dupla prioridade continua a sobrepor-se à relação entre a Alemanha e a Rússia.

A diplomacia da Alemanha assenta assim numa estratégia de inserção da Rússia no quadro securitário euro-atlântico, que tem evitado que Berlim tenha que escolher entre relações com a Rússia e uma Ostpolitik com os países do Cáucaso, alguns deles interessados a aderir às instituições ocidentais: com a Rússia, a Alemanha está antes de mais interessada em cooperar economicamente e garantir o fornecimento de energia, e logo a segurança energética; com a Ucrânia e a Geórgia, Berlim aceita a adesão longínqua de ambos à UE preferindo promover por agora a Parceria Oriental, ao mesmo tempo que reconhece que com a OTAN a lógica de adesão segue objetivos diferentes, e que afetam a relação com Moscovo, já que a Rússia se opõe ao alargamento institucional da mesma para junto das suas fronteiras.

Estes contextos diferenciados levam-nos a uma situação paradoxal: enquanto que a Rússia não se conforma com a perda de estatuto de grande potência mundial, e define as suas opções externas em função deste predicamento, a Alemanha, vinte e três anos depois da unificação, não aceitou ainda as consequências da expetativa de liderança que a desafiam quanto a uma estratégia de política externa europeia e internacional mais assertiva. Ou seja, enquanto que a Rússia prossegue uma estratégia de revisão dos contornos da ordem europeia do pós-Guerra Fria, a Alemanha é defensora do status quo sem aceitar que para manter essa ordem terá de assumir um papel de liderança. O paradoxo daí resultante é que a Rússia quer ser a grande potência europeia do espaço euro-atlântico mas não consegue, ao passo que a Alemanha exerce influência e ganhou auto-confiança mas permanece cautelosa e hesitante em afirmar-se enquanto grande potência europeia. Enquanto a primeira quer mais do que as capacidades lhe permitem, a segunda, apesar das expetativas de alguns parceiros e da 
potência económica evidente abstém-se de exercer, uma política externa mais assertiva no espaço euro-atlântico e na sua vizinhança (Daehnhardt, 2012). Esta tensão subjacente à discrepância entre capacidades e vontade política existe nas políticas externas tanto da Rússia como da Alemanha.

A acrescentar a isso, existe um conjunto de elementos idiossincráticos que condicionam a perceção que os decisores políticos transportam para a política externa, com uma diferenciação clara entre a narrativa russa e a narrativa alemã da política internacional e do papel que cada um dos países desempenha nela (Freire e Daehnhardt, 2011, pp.175-79). Para a Rússia, a conceção das relações internacionais é soberanista e vestefaliana, onde os interesses nacionais russos orientam a política externa. Partindo da premissa que a política externa é moldada pela identidade internacional de um país, a Rússia tem assumido uma identidade nacional(ista) assente numa visão tradicionalista e geopolítica que prossegue a recuperação do estatuto de poder e a criação de uma zona de influência no espaço pós-soviético (Tsygankov, 2006). O recurso ao uso da força militar (hard power) segue uma leitura russa do mesmo, quando considera interesses seus ameaçados e onde se atribui um droit de regard para intervir unilateralmente. Num plano internacional, e no seio das Nações Unidas, contudo, a Rússia reflete grande hesitação no uso conjunto da força militar, por não subscrever o princípio da ingerência nos assuntos internos (por razões humanitárias), receando que esse princípio possa vir a ser aplicado contra ela. Por outras palavras, a Rússia mantém uma perspetiva realista das relações internacionais, e rege-se por princípios que não se guiam pela tool box ocidental dos instrumentos ao dispor dos Estados, condicionados por um forte código normativo, mas define os seus objetivos e formas de os alcançar em função dos interesses da Rússia.

Em contrapartida, a conceção da Alemanha da política internacional contrasta com a perspetiva russa por basear-se numa conceção pós-soberanista da política internacional que aceita a limitação da soberania dos Estados por razões de integração multilateral ou por razões de ingerência humanitária. Constata-se a preferência pelo multilateralismo, pelo soft power e por princípios da boa governabilidade o que se repercute 
na europeização de vários setores da política alemã (Daehnhardt, 2011b e Daehnhardt, 2013a). A União Europeia afirma-se como o quadro de referência essencial, mesmo existencial para a defesa dos seus interesses e para amortecer o seu percurso de normalização da política externa condicionada por constrangimentos legais e morais que explicam a relutância da Alemanha face ao uso da força militar e que tem levado Berlim a considerá-lo apenas como último recurso, por razões humanitárias, preferencialmente com um mandato das Nações Unidas, e assumindo uma posição multilateral com os seus aliados. Por vezes esta relutância sobrepõe-se ao princípio do multilateralismo, levando Berlim a divergir da postura dos seus parceiros da Aliança Atlântica, como aconteceu em 2003, sobre a guerra no Iraque e em 2011, sobre a intervenção militar na Líbia. Isso já produziu o efeito adverso de uma convergência paradoxal de posições onde Berlim e Moscovo se posicionaram de forma semelhante, ou pela oposição a uma resolução proposta, como aconteceu com o Iraque, em 2003 ou abstendo-se, como aconteceu com a resolução sobre a Líbia, em 2011, se bem que por motivos distintos. ${ }^{38}$

O conjunto das características referidas define assim dois códigos "genéticos" diferenciados e colocam a Rússia e a Alemanha nas duas extremidades do quadro narrativo que molda a atuação externa no espaço euro-atlântico, com a Rússia crítica de uma ordem pós-moderna e desconfiada de princípios que se pretendam sobrepor à ordem soberanista. A Alemanha continua, mesmo que em menor grau do que antigamente, a ser condicionada pela memória histórica e a privilegiar, apesar da crise das dívidas soberanas que ameaçam a sobrevivência do euro, o multilateralismo e a integração europeia. Neste quadro normativo a política alemã é fundada na premissa de que a cooperação política e económica com o ocidente poderá resultar numa progressiva

38 A abstenção da Alemanha quanto à aprovação da Resolução 1973 de 17 de março de 2011 sobre a aplicação de uma zona de exclusão aérea sobre a Líbia foi duramente criticada; o que agravou a leitura da posição alemã foi o facto de a Rússia, juntamente com a China também se terem abstido, o que colocou o voto alemão numa luz ainda mais problemática, já que a abstenção alemã, em comparação com a abstençao russa e chinesa podia ser interpretada mais como um 'não' do que uma mera abstenção. 
integração da Rússia no espaço securitário euro-atlântico através da aceitação de normas e valores europeus, ao passo que a Rússia, na subscrição de uma conceção menos normativa e não recíproca, não se vê condicionada a atuar nesse sentido.

\section{A relação entre a Rússia e a Alemanha}

A relação entre a Rússia e a Alemanha caracteriza-se por consultas bilaterais anuais entre o presidente russo e o chanceler alemão e entre diferentes ministros que abordam as relações bilaterais nos domínios político, económico, energético, de segurança e cultural. A centralidade da relação económica levou à institucionalização da cooperação e desde 2000, realizam-se regularmente, geralmente duas vezes por ano, reuniões bilaterais do Grupo de Trabalho Estratégico da Economia e das Finanças onde representantes políticos e empresariais abordam questões económicas e financeiras. Estes contatos regulares ao mais alto nível revelam a posição da Alemanha como principal parceira económica da Rússia. Para além do relacionamento entre as estruturas governamentais, foi criado, em 2001, pelo presidente russo Vladimir Putin e o chanceler alemão, Gerhard Schröder, o "Diálogo de Petersburgo", um fórum de discussão que se realiza anualmente para promover o aprofundamento das relações entre as duas sociedades civis nos domínios da política, economia, educação e ciência, cultura e media. 39

39 O Diálogo de Petersburgo, que nos últimos anos se transformara num fórum ritualizado representado, por parte da Rússia, por antigos funcionários do Kremlin, mais do que representantes da sociedade civil russa, foi revitalizado, da parte alemã, em abril de 2012, quando a chanceler Merkel nomeou Andreas Schockenhoff, vice-presidente da CDU/ CSU no Bundestag e coordenador para a Rússia do seu governo para chefiar o grupo de trabalho do "Diálogo de Petersburgo". Desde então, a posição alemã tem vindo a endurecer o discurso, como aconteceu, por exemplo, na condenação do caso Pussy Riot, um grupo de música, cujos membros foram condenados, em agosto de 2012 a dois anos de prisão, detidos sob acusação de ódio religioso e hooliganismo por terem atuado, em fevereiro de 2012 numa igreja, apelando à deposição de Putin. Ver "Kreml kritisiert CDU-Politiker Schockenhoff”, Frankfurter Allgemeine Zeitung, 14 agosto 2012. Disponível em: http:// www.faz.net/aktuell/politik/ausland/prozess-gegen-pussy-riot-kreml-kritisiert-cdu-politiker-schockenhoff-11855427.html. Consultado em: 12 setembro 2012. 


\section{A relação económica}

A relação bilateral económica e energética com a Alemanha é fundamental para a Rússia que necessita dos investimentos de empresas alemãs e do mercado energético alemão (e europeu) para escoamento das suas exportações, compostas primordialmente por recursos energéticos como o gás natural e o petróleo. A Alemanha é um ator chave no contexto euro-atlântico: é a maior economia europeia, a quinta maior economia no mundo e detém um papel importante nas instituições económicas internacionais como o G8 e o G20. É, depois da China, o segundo maior país exportador no mundo e, perante as adversidades da crise na zona euro, tem conseguido manter algum crescimento económico e uma forte indústria exportadora, afirmando-se como potência geoeconómica (Kundnani, 2011). É por isso, inevitavelmente, um parceiro económico atraente para a Rússia tornando-se o seu principal parceiro comercial europeu. Por outro lado, a UE é fundamental à modernização económica russa tendo a diplomacia russa se esforçado por desenvolver uma relação dinâmica com alguns Estados membros, especialmente através de 'alianças para a modernização' bilaterais com a Alemanha, a França e a Itália. A posição chave que a Alemanha assume em Bruxelas é relevante na definição das relações entre a UE e a Rússia e nos recursos que Bruxelas está disposta a disponibilizar a Moscovo.

A relação económica russo-alemã existe desde há longa data, sendo a Rússia a quarta maior parceira comercial da Alemanha fora da UE. Por seu turno, a Alemanha foi, até 2010, o maior parceiro comercial da Rússia, tendo sido ultrapassada pela China, mas mantendo-se como o segundo parceiro a nível mundial e um importante mercado para as exportações da Rússia na UE.

O volume comercial entre os dois países aumentou significativamente entre 2000 e 2008 e voltou a aumentar em 2011, após um abrandamento em 2009 e 2010, atingindo o volume de comércio transacionado um valor máximo de 75 mil milhões de euros. ${ }^{40} \mathrm{Em} 2011$, as exportações alemãs

40 Os números que se seguem nesta secção foram consultados no Gabinete Federal de Estatística alemão (Statistische Bundesamt, Destatis), quando não assinalados de outra forma. 
para a Rússia aumentaram 30.5\%, alcançando 27 mil milhões de euros e as importações da Rússia aumentaram $27 \%$ perfazendo 25 mil milhões de euros. ${ }^{41} \mathrm{Em} \mathrm{2007}$, por exemplo, quase $70 \%$ das importações alemãs da Rússia eram produtos energéticos, tendo o petróleo e o gás natural sido os principais produtos importados no valor de 28.8 mil milhões de euros. Cerca de $15 \%$ das importações provenientes da Rússia foram metais como o ferro e o aço. Por seu turno, a Rússia depende da relação comercial com a Alemanha devido à necessidade de modernização da sua economia para a qual os investimentos alemães são indispensáveis. A Alemanha é dos países que mais investe na Rússia, tendo, em 2009, investido cerca de 13 mil milhões de euros. Apesar da crise económica e financeira, principalmente na zona euro, os dois países têm vindo a aprofundar a sua relação económica.

A Rússia ocupou, em 2011, o décimo segundo lugar dos países destinatários das exportações alemãs, no valor de 34.4 mil milhões de euros. ${ }^{42}$ Da parte das exportações russas para a Alemanha, estas ocuparam o sexto lugar, no valor de 40.5 mil milhões de euros. De acordo com o Ost-Ausschuss der Deutschen Wirtschaft (Comissão de Leste da Economia Alemã) esta situação poderia ser melhorada se existisse uma zona de livre comércio e se se procedesse à abolição, discutida desde 2003, do sistema de vistos entre os países do espaço Schengen e a Europa oriental, incluindo a Rússia. Como consta de um documento da Comissão publicado em novembro de 2011,

"A criação de um espaço económico harmonioso de Lisboa a Vladivostok é um dos grandes desafios da próxima década. Para não perder definitivamente a sua influência no palco da economia mundial face aos EUA e países asiáticos emergentes as economias europeias devem interligar-se mais com as economias fora do espaço da UE. A obrigatoriedade de vistos com muitos países vizinhos da Europa oriental é um dos maiores obstáculos ao comércio internacional. Especialmente o país exportador, a

41 "Rekordergebnis für Exporte nach Osteuropa", 2 março 2012. Disponível em: http://www. ost-ausschuss.de/rekordergebnis-f-r-exporte-nach-osteuropa. Consultado em: 12 março 2012.

42 Informação disponível em: http://www.ost-ausschuss.de/rekordergebnis-f-r-exporte-nach-osteuropa. Consultado em 12 março 2012. 
Alemanha tem um interesse fundamental em fazer progressos neste domínio." (Comissão de Leste da Economia Alemã, 2011, p. 5)

Enquanto que a Rússia é favorável à abolição dos vistos, alguns países da UE, entre os quais a própria Alemanha, colocam entraves à supressão dos mesmos por preocupações relacionadas com a segurança e o receio da imigração ilegal para o espaço comunitário. Isto revela que enquanto os setores económico e industrial alemães têm fortes interesses na intensificação da relação, exercendo pressão sobre o governo, a condução política da relação económica encontra-se condicionada por considerações políticas orientadas pela narrativa alemã acima descrita, mesmo que reúna consenso entre a elite política e económica alemã que uma crescente integração da economia russa nos mercados do espaço euro-atlântico serve para atenuar a rivalidade estratégica russa para com o ocidente.

\section{A relação energética}

A questão da segurança energética tornou-se uma das questões centrais da política externa. Para além dos benefícios económicos, os vastos recursos energéticos de que a Rússia dispõe no seu território são uma fonte de prestígio internacional que Moscovo instrumentaliza para projetar poder político no plano internacional. São, ao mesmo tempo, uma moeda de troca que os decisores russos têm utilizado para exercer pressão política e diplomática sobre Estados vizinhos e parceiros europeus, ou, em alguns casos, como instrumento para forçar uma alteração do posicionamento externo de um país vizinho, como aconteceu com a Ucrânia, em 2006 e 2009. A Rússia usa as exportações energéticas como instrumentos da sua política externa, sendo a companhia petrolífera russa Transneft um veículo de pressão sobre as exportações de petróleo, e a companhia de extração de gás natural Gazprom um veículo de pressão sobre as exportações de gás. Na vizinhança da Rússia, este tipo de pressão recai principalmente sobre a Ucrânia, a Bielorrússia e a Moldova por serem países de trânsito no fornecimento de gás russo para a UE. 
Uma componente importante do relacionamento económico bilateral entre Berlim e Moscovo é o fornecimento de energia russa à Alemanha. Mais de dois terços das importações alemãs da Rússia são recursos energéticos e quase um terço do consumo energético alemão de petróleo e gás natural é proveniente da Rússia. A Rússia é o maior fornecedor de energia da Alemanha desde a década de 1970, e continua a ser o maior fornecedor de gás natural para o mercado de gás alemão, tendo exportado, em 2007, 36\% do gás que a Alemanha importa, seguida pela Noruega e os Países Baixos que para aí exportam 26\% e 18\%, respetivamente (Bayer, 2009, p. 420). Entre 2008 e 2012, a Rússia manteve-se como a principal fornecedora de gás e petróleo para a Alemanha. ${ }^{43}$ Esta relação sugere uma maior dependência da Alemanha da Rússia, do que o inverso, já que a Alemanha importou, em 2011, 39.8\% do gás da Rússia (e 40.6\% de petróleo), representando o maior consumidor das exportações de energia da Rússia na Europa. ${ }^{44}$ No seio da UE, a Alemanha tem apoiado a entrada de companhias de energia russas no mercado europeu de energia, sublinhando que esta abertura reduziria os incentivos russos para manipular o fornecimento energético à Europa.

Perante a inexistência de uma política energética comum da UE, e de uma política europeia única para a Rússia, a Alemanha prossegue a relação energética bilateralmente. Assinou, em 2005, o projeto Nord Stream, como forma de garantir o acesso alemão ao gás natural russo e o seu transporte para a UE, assegurando que a rota de fornecimento ligasse a Rússia diretamente à Alemanha através do Mar Báltico, contornando os países bálticos e a Polónia cujas reações foram previsivelmente negativas ao projeto, o que se explica também pela perspetiva política que o então chanceler

43 Ranglisten für den Außenhandel Deutschlands nach Warenkategorien für das Jahr 2012, Außenwirtschaftsportal Bayern, Fonte: Statistische Bundesamt. (Posição dos parceiros económicos no comércio exterior da Alemanha, por categoria de produto para o ano de 2012), Disponível em: http://www.auwi-bayern.de/awp/inhalte/Laender/Warenkategorien/ kat/GP09-06/Erdö1\%20und\%20Erdgas/\#. Consultado em: 12 março 2013.

44 Discurso do Embaixador alemão em Moscovo, Ulrich Brandenburg, em 30 agosto de 2012, em Magdeburgo. Disponível em:

http://www.moskau.diplo.de/Vertretung/moskau/de/05/05-klima-energie/vortrag-botschafter-energiebeziehungen.html. Consultado em 12 setembro 2012. 
Schröder defendia, de uma aliança geopolítica e geo-económica entre as duas potências continentais euroasiáticas, integrando-as economicamente e reforçando a ligação política. Esta "parceria de modernização" faria com que a Rússia proporcionasse os recursos energéticos, enquanto que a Alemanha disponibilizava as tecnologias. $\mathrm{O}$ aumento dos laços bilaterais entre a Alemanha e a Rússia, no entanto, não é necessariamente contrário aos interesses europeus já que o gasoduto Nord Stream tem como objetivo fornecer gás natural russo à UE. Mas as implicações políticas do acordo bilateral evidenciavam a proximidade política entre Schröder e Putin e a forma como esta proximidade se traduzia em ganhos económicos, por vezes à custa dos parceiros da Alemanha.

A estratégia de Moscovo, por seu turno, é a de controlar as rotas de exportação de gás da Ásia Central para a Europa e adquirir uma influência crescente sobre o mercado energético europeu. Estes interesses estratégicos refletem-se, por exemplo, nas ações da empresa Gazprom, que pretende investir nas companhias alemãs E.ON Rubrgas ou BASF para entrar no mercado de gás alemão e assegurar uma posição importante em todo o mercado energético. Por outro lado, serve como meio de pressão sobre uma participação da Alemanha no projeto South Stream, rival do projeto Nabucco, proposto há uma década e que prevê o acesso europeu a gás natural do Cáspio e da Ásia Central através da Turquia e dos Balcãs, evitando a passagem por território russo (Westphal, 2011). O monopólio da Gazprom assim como as suas políticas de preço e falta de transparência nas políticas energéticas e de transferências económicas são igualmente motivos de preocupação do ocidente (Smith, 2010). Nesse sentido, a Alemanha tem tentado diversificar as fontes de fornecimento energético como aconteceu, por exemplo, com o Cazaquistão, o país com as quintas maiores reservas de recursos conhecidas no mundo. Em fevereiro de 2012 a chanceler Merkel recebeu Nursultan Nesarbaijev, presidente do Cazaquistão, em Berlim, tendo sido assinado um contrato comercial de exploração de recursos naturais por empresas alemãs. Por outro lado, a nova política energética alemã de 2011 de eliminação gradual da energia nuclear até 2022, requer uma nova política para a Rússia, já que as importações de gás poderão crescer significativamente e aumentar a 
dependência alemã do gás russo e os riscos associados à sua segurança económica, o que limitará a sua margem de manobra negocial.

\section{Segurança europeia e transatlântica}

A relação da Rússia com a Europa e com os Estados Unidos no quadro securitário euro-atlântico permanece, mais de duas décadas depois do fim da Guerra Fria e do fim da União Soviética, uma relação complexa e ambígua. Para alguns autores, os avanços neste domínio são tão precários, que se pode falar apenas de uma 'Paz Fria' que substituiu a 'Guerra Fria' (Sakwa, 2011; Karaganov, Teltschik e Olechowski, 2011). A complexidade prende-se mais com o contexto inerente ao espaço euro-atlântico do que ao espaço exterior a ele.

Moscovo distingue entre diferentes anéis de atuação: em primeiro lugar, o território da antiga URSS, o 'estrangeiro próximo' face ao qual a Rússia se reserva um droit de regard onde não aceita a interferência de países europeus; este espaço está longe de ser uma zona pacificada já que se caracteriza pela existência dos chamados 'conflitos congelados' da zona da Transnístria, na Moldova, do Nargorno-Karabakh, no Cáucaso do Sul, assim como as divergências entre a Rússia e a Geórgia quanto às regiões separatistas da Abcázia e da Ossétia do Sul. Estas questões destabilizam não apenas a vizinhança da Rússia mas afetam as relações entre Moscovo e o ocidente, produzindo uma competição latente pelo 'estrangeiro próximo' como lhe chama a Rússia ou a 'vizinhança europeia' como lhe chama a UE e que teve o seu auge com a guerra da Geórgia, em agosto de 2008. Esta guerra que opôs a Rússia à Geórgia numa disputa sobre a soberania da Abcázia e Ossétia do Sul, duas repúblicas secessionistas de Tbilisi provocou uma reação contida por parte da Alemanha, combinando o apoio à mediação do presidente francês Nicholas Sarkozy, enquanto líder da presidência rotativa da UE, com a não hostilização aberta de Moscovo. Poucos meses antes, na cimeira da OTAN, em Bucareste, em abril de 2008, a Alemanha e a França opuseram-se à aplicação do Membership Action Plan (MAP) da Geórgia e da Ucrânia à OTAN, ficando 
este objetivo norte-americano adiado sine die devido às preocupações franco-alemãs em não hostilizar Moscovo. ${ }^{45}$ Como o estatuto de segurança destes países e dos restantes quatro da Parceria Oriental ainda está por resolver, mantém-se a competição entre a Rússia, a UE e os EUA quanto à projeção de influência na definição do quadro de segurança inacabado do espaço euro-atlântico. É nesta zona precisamente que a leitura russa do seu 'estrangeiro próximo' entra em choque com a leitura da UE de 'vizinhança europeia' na qual a UE pretende projetar o seu modelo liberal democrático e onde, como afirmou Robert Kagan, a Rússia do século XIX choca com a União Europeia do século XXI (Kagan, 2008). Enquanto a Alemanha e a UE pretendem alargar a ordem de integração europeia vigente nas suas fronteiras, a Rússia pretende alterar esse modelo de ordem e assegurar a sua perspetiva tradicional de projeção de influência.

Em segundo lugar, o anel definido pelo quadro de segurança existente no espaço euro-atlântico mais amplo, onde a perspetiva securitária da Rússia converge seletivamente com as posições da UE e dos EUA na identificação de interesses comuns. A relação entre a OTAN e a Rússia nunca foi por isso uma relação livre de controvérsia (Kramer, 2010). A criação do Ato Fundador sobre Relações Mútuas, Cooperação e Segurança OTAN-Rússia, em 1997, institucionalizou a relação bilateral, enquanto o Conselho OTAN-Rússia, de 2002, tornou a Rússia um parceiro privilegiado da OTAN. Contudo, este formato equivalia à baixa probabilidade de a Rússia vir a tornar-se um membro da Aliança.

A prolongada ou permanente exclusão da estrutura transatlântica como membro de pleno direito tem levado Moscovo a seguir uma estratégia de, por um lado, tentar dividir os aliados e afastar os EUA da Europa e, por outro, influenciar as decisões sobre a segurança europeia de forma a incluir interesses estratégicos russos, o que tem resultado numa linha pouco definida em relação ao ocidente já que Moscovo se mostra ora cooperativo ora conflituoso com o mesmo. É principalmente em relação aos países da

45 Membership Action Plan ou 'Plano de Ação para a Adesão' (MAP) é um programa da OTAN, que prepara países que pretendam tornar-se membros da Aliança. O MAP não é contudo uma garantia de uma futura adesão à OTAN. 
Europa de leste, a antiga zona de influência da União Soviética que Moscovo tem revelado menos inibições em opor-se ao alargamento da OTAN durante a década de 1990 ou assumir posições conflituosas, realizando ataques cibernéticos contra os Estados Bálticos, aumentando as tarifas alfandegárias à Polónia, opondo-se à independência do Kosovo ou explorando tensões étnicas nos Balcãs para minar os esforços de estabilização regional da UE. Para além disso, a oposição russa ao projeto de defesa antimíssil para a Europa, defendido pelos EUA, evidencia a dificuldade de estabelecimento de um verdadeiro quadro de segurança euro-atlântico. ${ }^{46}$ Esta ambiguidade russa reflete-se também na sua doutrina militar, adotada em fevereiro de 2010, e que identificou explicitamente a OTAN e o seu alargamento para o leste europeu como representando uma ameaça militar para a Rússia. O discurso russo face aos países ocidentais sublinhava repetidamente que o aparecimento de infra-estruturas estratégicas norte-americanas na proximidade imediata das suas fronteiras será interpretado como uma ameaça à sua segurança. Nesse sentido, o relatório do grupo de peritos sobre o novo conceito estratégico da OTAN, de maio de 2010, afirmava que “a Rússia enviou sinais conflituosos quanto à sua abertura à cooperação contínua com a OTAN, e as suas propostas para uma ordem de segurança alternativa na Europa parecem desenhadas em parte para constringir as atividades da OTAN" (OTAN 2020, 2010, p. 26).

Por último, Moscovo define um terceiro anel de actuação, fora do espaço euro-atlântico, caracterizado pelas ameaças globais como o terrorismo internacional, a proliferação das armas de destruição maciça, o crime mundial

46 O projeto de defesa balística de mísseis continua a ser uma das principais divergências entre a Rússia e os EUA/OTAN. Os EUA e a OTAN pretendem construir um sistema de mísseis anti-balísticos na Europa, destinado a dissuadir potenciais ataques dirigidos do Irão à Europa ou aos EUA. A Rússia, contudo, teme que a implantação deste sistema anti-míssil na Europa seja dirigido contra os seus arsenais nucleares tornando a dissuasão nuclear russa vulnerável. Os países ocidentais e particularmente os EUA têm reservas sobre o grau de partilha de informações a que a Rússia estará disposta no desenvolvimento de um sistema de defesa anti-míssil conjunto e onde a forma de acesso ao comando de tal sistema (um único como defende Moscovo ou dois sistemas separados como defendem os membros da OTAN) permanece um ponto de discórdia. Apesar dos EUA, a Alemanha, e a OTAN terem proposto a cooperação com a Rússia neste projeto, Moscovo exige que a OTAN assine com a Rússia um tratado internacional que lhes permita controlar o sistema. A OTAN, em contrapartida, oferece apenas garantias políticas de que o sistema não visa a Rússia, em boa parte porque um tratado internacional desse tipo não seria ratificável no Senado dos EUA. 
organizado, assim como ameaças emergentes de países como o Irão e a Coreia do Norte, a incerteza securitária do Afeganistão após a retirada das forças da OTAN, em 2014, ou a instabilidade política que permanece no Médio Oriente, acentuada pela chamada Primavera Árabe. Ao contrário do que acontece nos primeiros dois anéis, aqui existe alguma convergência de interesses e cooperação securitária entre a Europa, os EUA e a Rússia, se bem que as mudanças políticas no Médio Oriente, em particular na gestão das crises da Líbia e da Síria, decorrentes da Primavera Árabe, ou a prolongada questão nuclear do Irão não têm levado a posições conjuntas. ${ }^{47}$

Pela permanência desta ambiguidade do relacionamento entre a Rússia e os restantes atores do espaço euro-atlântico, a relação bilateral com a Alemanha tornou-se ainda mais relevante no pós-Guerra Fria e produz implicações no quadro político-securitário euro-atlântico que Moscovo tenta aproveitar. Para atenuar essas divergências, a Alemanha tem seguido o princípio de que a Rússia deve ser tratada como parceira e não como adversária: será apenas através da inclusão da Rússia no quadro de segurança europeu que se consegue alcançar a estabilidade na Europa e que as grandes crises internacionais poderão ser resolvidas com Moscovo como importante parceiro na resolução de questões internacionais em zonas como o Médio Oriente ou os Balcãs. Um dos defensores mais ativos deste princípio foi o antigo ministro dos negócios estrangeiros alemão Frank-Walter Steinmeier (SPD), quando sugeriu uma nova Ostpolitik, em 2006-2007, baseada na "reaproximação através da interdependência económica" (“Annäherung durch Verflechtung”) e numa ordem de paz europeia estável, democrática e de vigência do direito nos países vizinhos da UE (Steinmeier, 2006). Isto pressupunha a participação da Rússia, servindo o reforço dos laços políticos, económicos e culturais entre a UE e a Rússia para garantir a estabilidade nas fronteiras da UE.

Da parte russa pretendia-se capitalizar esse apoio alemão. Em junho de 2008, o presidente russo Dmitri Medvedev afirmou num discurso, em

47 A Alemanha tem votado a favor das resoluções do Conselho de Segurança das Nações Unidas sobre a Síria que condenam o regime do presidente sírio Bashar al-Assad e a guerra civil em curso, enquanto a Rússia (e a China) tem repetidamente, desde outubro de 2011, vetado resoluções que prevejam a aplicação de sanções ao regime de Damasco. 
Berlim: "A importância da reconciliação russo-alemã é claramente subestimada. É tão importante para o futuro pacífico da Europa como foi, digamos, a reconciliação entre a França a e Alemanha" (Medvedev, 2008a). Nesse discurso, Medvedev falou pela primeira vez publicamente numa nova arquitectura de segurança europeia e transatlântica, de Vancouver a Vladivostok, sem ser muito específico quanto aos contornos da mesma. Sem a rejeitar, Berlim reagiu à proposta com alguma hesitação: apoiá-la decididamente levaria a críticas de desunião na Aliança Atlântica; rejeitá-la abertamente desincentivaria Moscovo a manter-se interessado no quadro de estabilização na Europa que a Alemanha considera vital.

Em finais de 2009, na primeira reunião OTAN-Rússia após a guerra com a Geórgia, Medvedev lançou uma proposta mais formal, no novo contexto da política do reset da administração norte-americana da Barack Obama que pretendia relançar as relações depois do desaire sobre a Geórgia. $\mathrm{Na}$ realidade, contudo, continuava a não existir uma convergência de interesses entre as partes que permita um avanço quanto à iniciativa russa: enquanto a Rússia pretendia uma renegociação das estruturas de segurança europeias, ou seja, uma substituição das antigas estruturas por um novo quadro securitário, cujos termos seriam primordialmente definidos por Moscovo, a UE - e a Alemanha - tentavam resolver os problemas dentro do quadro securitário existente concebendo mecanismos de resolução de conflitos dentro da UE e mantendo inalterada a importância da OTAN e da presença dos EUA na Europa (Makarychev, 2009b).

Nos meses que antecederam a Cimeira da OTAN, em Lisboa, em novembro de 2010, as iniciativas russo-alemãs multiplicaram-se, revelando mais uma vez a importância que a Alemanha assume para a Rússia como parceiro preferencial no lançamento de propostas vindas de Moscovo. Em 6 de junho de 2010 Merkel e Medvedev propuseram a criação de um Comité Político e de Segurança UE-Rússia, para uma cooperação mais estreita em questões de segurança. Este memorando de Meseberg, como ficou conhecido, sugeria a realização de reuniões a nível ministerial, entre a Alta Representante para a Política Externa e de Segurança, Catherine Ashton e o ministro dos negócios estrangeiros russo, Sergej Lavrov. Segundo o comunicado, o Comité deveria "tornar-se um fórum de troca 
de perspetivas sobre assuntos atuais de política e segurança internacional" e servir para desenvolver "linhas orientadoras quanto a operações civis e militares conjuntas no domínio da gestão de crises" (Memorando de Meseberg, 2010). Esta iniciativa bilateral apanhou os restantes membros da UE e a Comissão Europeia de surpresa, e apesar de a iniciativa não ter tido seguimento ilustrou como Berlim qualificava Moscovo como essencial na definição do quadro de segurança europeu ao passo de lançar propostas conjuntas sem conhecimento prévio dos seus parceiros europeus. Dos cinco pontos do comunicado consta uma referência específica à cooperação entre a UE e a Rússia com vista à resolução do conflito da Transnístria sugerindo atividades conjuntas "que garantam uma transição suave da situação atual até à fase final." Berlim tentou estabelecer uma ligação entre a proposta de criação do acima referido Comité Político e de Segurança UE-Rússia e a tentativa de resolução da situação nesta região separatista da Moldova porque vê o caso da Transnístria como um test case das relações de segurança entre a Alemanha e a Rússia na Europa. Contudo, para os decisores russos a resolução deste conflito é vista como contrária aos interesses russos, já que levaria a uma perda de influência russa e aceleraria a integração da República da Moldova na UE. Claramente, as divergências entre a perspetiva alemã de resolução de conflitos e a perspetiva russa quanto aos mesmos pode ser aplicada a outros conflitos de países que integram a Parceria Oriental, como o caso do Nagorno-Karabakh, entre a Arménia e o Azerbaijão, e o caso da Abcázia e da Ossétia do Sul, entre a Geórgia e a Rússia: uma resolução dos mesmos aproximaria estes países mais à UE, ao passo que a sua continuação mantem as partes na dependência da Rússia.

Ainda em 2010 várias personalidades alemãs manifestaram-se a favor de uma redefinição do relacionamento político e de segurança dos países ocidentais com a Rússia. Em 14 de janeiro de 2010, o então secretário de estado alemão dos Assuntos Europeus, Werner Hoyer (FDP), sugeriu uma nova dinâmica na política do Conselho OTAN-Rússia que incluísse uma política da porta aberta da OTAN em direção a Moscovo (Hoyer, 2010). Para Hoyer a criação de um quadro de segurança europeia duradouro dependeria da adesão da Rússia à “aliança de segurança das democracias 
ocidentais do espaço euro-atlântico" devendo a OTAN manter a sua 'Open-door policy' em relação a Moscovo.

Numa carta aberta publicada no semanário alemão Der Spiegel, em março de 2010, a antigo ministro alemão da defesa, Volker Rühe, o ex-general da Bundeswehr, Klaus Naumann, o antigo diplomata, Frank Elbe e um antigo chefe de gabinete do ministério da defesa, Ulrich Weisser sugeriram a adesão, no futuro, e segundo critérios previamente acordados, da Rússia à Aliança Atlântica argumentando que, na defesa contra ameaças externas e para responder aos desafios colocados pelas dinâmicas transformadoras da multipolaridade emergente, largamente devido às potências asiáticas, a OTAN não estava preparada. Por isso, como entidade estratégica a Aliança deveria agrupar os três centros de poder: América do Norte, Europa e Rússia. Este trio, para estes autores, tinha interesses comuns que são ameaçados pelos mesmos desafios e que exigem por isso respostas comuns (Der Spiegel, 2010).

Dois diplomatas alemães, Wolfgang Ischinger, coordenador da Conferência de Segurança de Munique e antigo embaixador da Alemanha nos EUA e Ulrich Weisser, antigo chefe de gabinete do ministério da defesa publicaram um artigo conjunto, em junho de 2010, onde afirmaram que o desafio central para a OTAN era 'getting Russia right' (Ischinger e Weisser, 2010) e onde uma diminuição da 'fricção permanente entre membros da OTAN quanto à Rússia poderia ser conseguida através de uma maior inclusão da Rússia num contexto negocial entre a OTAN, a UE e a Rússia, e a Alemanha e a Rússia, por exemplo, relativamente ao sistema de defesa anti-míssil, controlo de armamento convencional e nuclear. $\mathrm{O}$ apelo a uma comunidade de segurança euro-atlântica que reunisse estrategicamente a América do Norte, a Europa e a Rússia, sustentado por uma cooperação no projeto de defesa anti-míssil foi reiterado por Ischinger em maio de 2012 pouco antes da cimeira da OTAN em Chicago (Ischinger, 2012). Assim, a Rússia contava com o apoio de Berlim quanto às suas preocupações de segurança no sentido do reconhecimento por uma parte considerável da elite alemã do risco de marginalização das questões europeias e euro-atlânticas. Se bem que se tratou de posições individuais dentro da elite política alemã, a Alemanha era dos grandes 
Estados membros da OTAN aquele para quem uma futura, mesmo que longínqua hipótese de adesão russa à OTAN não era inconcebível.

\section{Quadros de cooperação alargados: França e Polónia}

Numa tentativa de resolver a contínua indefinição sobre os contornos da ordem europeia de segurança e um discurso russo que oscila entre a abordagem cooperativa e a hostilização do ocidente, a Alemanha tem vindo a promover dois quadros de cooperação alargados, nomeadamente com a França e com a Polónia. A primeira reunião triangular entre Berlim, Paris e Moscovo ocorreu em 1998, entre o chanceler Helmut Kohl, o presidente Jacques Chirac e o presidente Boris Ieltsin. Mas foi o encontro entre o chanceler Gerhard Schröder, o presidente Jacques Chirac e o presidente Vladimir Putin, em São Petersburgo, em abril de 2003, no auge da guerra do Iraque e quando os três líderes convergiram na crítica a Washington (e Moscovo e Paris convergiam no apoio à pretensão da Alemanha em tornar-se um membro permanente do Conselho de Segurança das Nações Unidas) que este formato ganhou maior relevância. O encontro foi seguido por reuniões triangulares anuais, com o objetivo da intensificação da cooperação económica, e onde questões de direitos humanos que integravam as agendas de Berlim e Paris acabavam por ser secundarizadas aos interesses económicos de três atores.

Mais recentemente, a Alemanha tem promovido a integração da Polónia na relação bilateral entre Berlim e Moscovo argumentando que o desentendimento entre Moscovo e Varsóvia, de meados da década de 2000 era prejudicial a progressos no relacionamento entre a UE e a Rússia. Assim, desde inícios de 2010 Varsóvia e Moscovo iniciaram um lento processo de reconciliação entre as elites políticas, tornando-se a Polónia um parceiro importante para a Rússia por várias razões para além da cooperação económica: primeiro, porque integra o grupo de Visegrado cujo foco securitário é a zona geográfica que engloba a Moldova, a Ucrânia e a Bielorrússia; segundo, porque partilha a costa marítima do Mar Báltico com os países bálticos e escandinavos, evidenciando também aqui questões 
securitárias no relacionamento com Moscovo. Aliás, a Parceria Oriental, que criou um quadro institucional próprio da UE com seis ex-repúblicas da União Soviética, em 2009, surgiu através de uma iniciativa bilateral entre a Polónia e a Suécia, com o apoio de Berlim, demonstrando a relevância da dimensão nórdica para Varsóvia. Terceiro, nos últimos anos, a Polónia provou ser o aliado da Europa central mais importante dos Estados Unidos, o que aumentou o seu poder negocial junto a Moscovo. Por último, a relação bilateral da Polónia com a Alemanha é decisiva, e o seu enquadramento no triângulo de Weimar, que, para além destes dois paises inclui a França, surge como complemento importante na diplomacia de Varsóvia.

A iniciativa de consultas trilaterais entre a Alemanha, a Rússia e a Polónia poderia produzir uma transformação qualitativa no relacionamento entre a Rússia e a UE, porque a Polónia surge como peça chave, ao legitimar uma nova dimensão de confiança e potencial reconciliação polaco-russa, por um lado, e ao retirar à relação bilateral entre Berlim e Moscovo a exclusividade que por muitos é vista como excessiva, por outro. Das tensões germano-polacas, em 2005, sobre como abordar a Rússia, ou o veto polaco sobre a renovação do Acordo da Parceria e Cooperação (APC) UE-Rússia em 2007, passou-se para uma abordagem germano-polaca face à Rússia no quadro securitário europeu. Da perspetiva da diplomacia russa, este formato é ainda visto como veículo para promover acordos regionais, principalmente a cooperação transfronteiriça, junto de Bruxelas, onde Berlim tem poder de alavancagem. O primeiro encontro do 'Diálogo Trilateral' ocorreu em Kaliningrado, em maio de 2011, e abordou questões sobre o fim dos vistos para residentes de Kaliningrado e a UE.

Em novembro de 2011, no decurso da presidência polaca da União Europeia, os ministros dos negócios estrangeiros alemão e polaco, Guido Westerwelle e Radoslav Sikorski, numa carta conjunta a Catherine Ashton, Alta Representante para a Politica Externa da UE, apelaram à UE para que adopte uma estratégia europeia para a Rússia para o aprofundamento da relação de cooperação, assumindo esta "o seu lugar apropriado numa Europa democrática de liberdade e prosperidade”. A UE deveria apoiar a modernização da economia e do sistema político e social russos, em troca 
de uma Rússia como "parceiro fiável no palco político e económico europeu" (Turkowski, 2011). Estas iniciativas sugerem o desenvolvimento de uma Ostpolitik multilateral germano-polaca, que joga a favor do aumento da influência da Alemanha ao mesmo tempo que facilita uma reconciliação russo-polaca. Mesmo assim, esta fórmula trilateral não tem até à data produzido os efeitos pretendidos. A relação entre estes três países é ainda dificultada, por um lado, pela inexistência de uma verdadeira política da UE para a Rússia, por outro, pelas divergentes prioridades que definem as atuações políticas dos três atores: a Polónia, orientada primordialmente por considerações geopolíticas no seu relacionamento com Moscovo, a Alemanha orientada primordialmente por considerações económicas e a Rússia, receosa do alargamento da OTAN para junto das suas fronteiras.

A potência ausente deste quadro de relacionamento bi e multilateral para a Rússia são os Estados Unidos. Em contrapartida à linha de continuidade que a diplomacia alemã segue em relação à Rússia, a política dos EUA para a Rússia orienta-se por um leque mais abrangedor de opções, da cooperação à confrontação política. Esta divergência subjacente às diferentes perspetivas de Berlim e de Washington face a Moscovo tem dificultado uma política americano-alemã face à Rússia (Szabo, 2010). Da mesma maneira que não existe uma política da UE para a Rússia, também não existe uma política continuamente convergente entre a Alemanha e os EUA face a Moscovo: se houvesse uma política bilateral americano-alemã para a Rússia esta teria menos margem de manobra. Da perspetiva de Washington, a ausência de um consenso estratégico europeu para a Rússia faz com que o poder negocial da Alemanha junto dos EUA aumente, já que Berlim se tornou o principal interlocutor junto de Moscovo. Ao mesmo tempo, a Alemanha é o parceiro indispensável para gerir a estabilidade do continente europeu e as relações entre a UE e a Rússia. É ainda importante no relacionamento entre a Aliança Atlântica e a Rússia, porque na sua gradual transformação de potência europeia para potência asiática, os EUA vão precisar da Alemanha para que esta assegure a estabilidade na Europa. Como afirmou Constanze Stelzenmüller, "a Alemanha é uma ponte entre a Rússia e o ocidente, e a forma como Berlim escolhe lidar com Moscovo irá marcar o tom como os 
Estados Unidos e o resto da Europa vão gerir as suas próprias relações com a Rússia" (Stelzenmüller, 2009). Por outras palavras, "não pode haver nenhuma estratégia ou política séria ocidental para a Rússia que não seja apoiada por Berlim" (Szabo, 2010). A crítica vinda de alguns analistas dos EUA é que a Alemanha põe a tónica excessivamente na cooperação, interdependência e parceria com a Rússia e que isto impede que capitalize uma abordagem conjunta Alemanha-EUA ou mesmo Europa-EUA face a Moscovo (Bergmann, 2009; Szabo, 2010).

A reeleição de Barack Obama, em novembro de 2012, não provocou uma revitalização da relação entre os EUA e a Rússia, impedida pelo fracasso da política norte-americana do reset, e o endurecimento da postura de Vladimir Putin no seu regresso ao cargo presidencial; para além disso, a deslocação estratégica dos EUA do espaço euro-atlântico para o Pacífico e a criação de uma rede de parcerias e instituições semelhantes às europeias (Clinton, 2011, p. 58) sugere uma desaceleração da relação bilateral quanto a questões europeias. Estes três factores reforçam, contudo, a importância da relação entre a Rússia e a Alemanha numa altura em que a diminuição do envolvimento norte-americano na Europa poderá levar ao aumento da tensão entre a Rússia e a Alemanha.

A defesa mútua de interesses energéticos e económicos confirma que o pragmatismo é ainda a característica que melhor define a relação bilateral entre a Rússia e a Alemanha. Mas o governo alemão e os deputados do Bundestag não esconderam a sua desilusão ao tomarem conhecimento, em setembro de 2011, da candidatura de Putin a um terceiro mandato presidencial, que interpretaram como sinal de desaceleração da modernização iniciada por Dmitri Medvedev e de recuo no gradual processo de democratização da Rússia. Isto pode representar o início do fim do consenso político quanto à Rússia com alguns autores a identificar uma crescente alienação nas relações russo-alemãs (Meister, 2012). Antigos defensores de uma maior proximidade à Rússia têm mudado de postura. O general Klaus Naumann, por exemplo, que em 2010 fora co-assinante da carta acima referida, escreveu poucos dias depois da eleição presidencial, em março de 2012, que a posição de Putin quanto à Síria mostrava 
que a Rússia tinha deixado de ser um parceiro aceitável para a OTAN. ${ }^{48}$ A chanceler Angela Merkel não manifestou, nos primeiros meses após a reeleição de Putin sinais de que pretenderia reestabelecer uma relação próxima como ela existira com Medvedev. A primeira visita de estado de Putin como novamente presidente da Rússia, para fora do 'estrangeiro próximo', foi a Berlim, em 1 de junho de 2012. Tratou-se de um encontro cordial, mas que simbolizou o esfriamento das relações bilaterais, e onde, para além das habituais conversações sobre a cooperação económica, o desacordo entre Berlim e Moscovo sobre a forma de se abordar, no Conselho de Segurança das Nações Unidas, a guerra civil na Síria, manifestou uma vez mais a oposição da liderança russa em aceitar princípios da ordem securitária subscritos por Berlim. Neste sentido, está a emergir um debate, em Berlim, sobre se a Ostpolitik alemã para a Rússia - promover a mudança através da cooperação, interdependência e parceria - produziu até hoje os resultados pretendidos no sentido de aproximar a Rússia do quadro de valores e normas ocidentais e sobre se é possível construir uma ordem securitária europeia entre atores que não partilham a mesma conceção política. A intransigência de Putin face à questão da Síria, ao defender o regime criticado pelo ocidente, a crescente crítica de Moscovo do projeto de defesa anti-míssil, a recusa de Putin em participar nas reuniões do G8 e da OTAN, nos Estados Unidos, em abril de 2012, exemplificam o mal-estar atual nas relações entre a Rússia e o ocidente. Perante um potencial retrocesso deste relacionamento, a Alemanha posiciona-se, cautelosa, numa postura de não hostilização aberta, mas de um maior distanciamento de Moscovo. As iniciativas trilaterais, com a Polónia e a França persistem, mas com menos intensidade e sem resultados concretos. A cooperação económica irá manter-se, mas é possível que o ponto alto do relacionamento da Rússia de Putin-Medvedev-Putin com a Alemanha já tenha sido ultrapassado, e que apenas com uma verdadeira transição na Rússia para um sistema democrático os dois lados se voltem a aproximar.

48 Citado em John Vinocur (2012) "Germany's 'unpolitical' new president", New York Times, 26 março. Dísponível em: http://www.nytimes.com/2012/03/27/opinion/germanys-unpolitical-new-president.html?_r=0. Consultado em: 23 abril 2012. 


\section{Conclusão}

Da perspetiva da Rússia, faz sentido continuar a privilegiar as relações com a Alemanha porque Berlim serve de ponte de ligação nas relações políticas com o ocidente que pode evitar um isolamento europeu da Rússia, para além dos óbvios interesses económicos e energéticos. Ter Berlim como o seu interlocutor preferencial no relacionamento com a UE, e, em menor grau, na relação com a OTAN e os EUA, continua a ser um trunfo da diplomacia russa que esta quererá manter. Os decisores russos sabem que não caberá à Alemanha individualmente decidir sobre a futura composição da OTAN, assim como não será Berlim a definir unilateralmente os contornos da ordem securitária euro-atlântica. Mas com a transformação da identidade internacional dos EUA, e sendo a Alemanha atualmente a única potência económica na crise das dívidas soberanas na Europa, saber que o apoio mais decisivo com que Moscovo poderá contar vem de Berlim, é uma mais valia no relacionamento da Rússia com o ocidente euro-atlântico. Nesse sentido, relacionar-se bilateralmente com a Alemanha é preferível a ter que lidar com uma posição europeia conjunta, já que em caso de divergências bilaterais os mecanismos institucionais entre Berlim e Moscovo podem amortecer potenciais desentendimentos.

Da perspetiva da Alemanha, a sua diplomacia tem conseguido equilibrar um relacionamento sui generis com a Rússia, com uma relação estreita com países da Europa central e oriental, principalmente a Polónia. A Alemanha, pelas razões apresentadas neste capítulo, é a potência europeia que tem sido melhor sucedida no desenvolvimento de uma relação próxima com a Rússia, também pelas considerações que tece sobre as sensibilidades do vizinho russo face à estabilidade da ordem europeia e transatlântica. Foi o que se verificou quando Berlim desacelerou o alargamento da OTAN à Geórgia e Ucrânia. É evidente que a dependência europeia, e especialmente alemã, do fornecimento de gás natural russo é um factor preponderante na definição da política alemã, mas a não hostilização diplomática de Moscovo orienta a diplomacia de Berlim.

Contudo, existem sinais de que a dinâmica desta relação pode estar a mudar, por parte de Berlim, e de que a falta de credenciais democráticas 
consolidadas dificultem o papel da Rússia como parceiro na construção de uma ordem securitária europeia pós-atlântica, onde os EUA terão, por opção, um papel mais reduzido. A Rússia continua a insistir na revisão da ordem europeia do pós-Guerra Fria, em ser o ator preponderante no seu "estrangeiro próximo" e em não deixar que os países ocidentais e o seu enquadramento normativo euro-atlântico imponham condicionalidade a Moscovo. Daí que a Rússia e a Alemanha deverão manter a cooperação económica e energética, mas não a qualquer custo. Para a coesão do espaço euro-atlântico, já por si desafiada pelo redireccionamento estratégico dos EUA para o Pacífico e a ascensão de potências asiáticas, isto significa mais e não menos riscos de tensão.

\section{Bibliografia}

Außenwirtschaftsportal Bayern (2013) "Ranglisten für den Außenhandel Deutschlands nach Warenkategorien für das Jahr 2012", Statistische Bundesamt. [Acedido a 12 de mar. de 2013]. Disponível na Internet: http://www.auwi-bayern.de/awp/inhalte/Laender/ Warenkategorien/kat/GP09-06/Erdöl\%20und\%20Erdgas/\#.

BAYER, Wolfgang - Das GETS-Projekt: Gaslieferungen von und nach Deutschland. Statistisches Bundesamt. N. ${ }^{\circ} 5$ (2009), p. 416-424. [Acedido a 27 de jul. de 2012]. Disponível na Internet: https://www.destatis.de/DE/Publikationen/WirtschaftStatistik/EnergieWasserversorgung/ GetsProjekt509.pdf?__blob=publicationFile.

Bergman, Max - Germany's Russia Moment. World Politics Review (2009). [Acedido a 27 de jul. de 2012]. Disponível na Internet: http://www.worldpoliticsreview.com/articles/3773/ germanys-russia-moment.

BRANDENBURG, Ulrich - Discurso do Embaixador alemão em Moscovo, em 30 agosto de 2012, em Magdeburgo. [Acedido a 12 de set. de 2012]. Disponível na Internet: http:// www.moskau.diplo.de/Vertretung/moskau/de/05/05-klima-energie/vortrag-botschafterenergiebeziehungen.html.

BULMER, Simon, JEFFERY, Charlie e PADGETT, Stephen, eds. - Rethinking Germany and Europe: Democracy and Diplomacy in a semi-sovereign state. Houndsmills, Basingstoke, Hampshire and New York: Palgrave Macmillan, 2010.

CARnaghan, Ellen, e HALE, Henry - Public Opinion Polls and Political Culture. Russian Analytical Digest, N. ${ }^{\circ} 117$ (2012). [Acedido a 24 de set. de 2012]. Disponível na Internet: http://www.css.ethz.ch/publications/pdfs/RAD-117.pdf.

CHIVVIS, Christopher e RID, Thomas - The Roots of Germany's Russian Policy. Survival. Vol. 51, N. ${ }^{\circ} 2$ (2009), p. 105-122.

CLINTON, Hillary - America's Pacific Century. Foreign Policy. N. ${ }^{\circ} 189$ (2011), p. 56-63.

DAEHNHARDT, Patricia - O fim da Guerra Fria e a Unificação Alemã. Relações Internacionais. N. ${ }^{\circ} 23$ (2009), p. 39-52. 
DAEHNhARDT, Patricia - A transformação da política europeia da Alemanha. Política Internacional e Segurança, N. ${ }^{\circ} 5$ (2011a), p. 53-75.

DAEHNHARDT, Patricia - Germany in the European Union. In Reuben Wong and Christopher Hill, eds. National and European Foreign Policy: Towards Europeanization. London: Routledge (2011b), p. 35-56.

DAEHNHARDT, Patricia - Germany's New Role in Europe: European Leadership, German Hegemony or None of Both? Artigo apresentado na conferência UACES 'Exchanging Ideas on Europe 2012: Old Borders - New Frontiers', Passau, Alemanha, 3-5 setembro 2012.

DAEHNHARDT, Patricia - Germany, the EU and a transforming domestic political arena. In M. Mannin and C. Bretherton, eds., The Europeanization of European Politics. Basingstoke: Palgrave Macmillan (2013a), p. 25-38.

DAEHNHARDT, Patricia - A implosão da URSS e a União Europeia. In Pedro Aires de Oliveira, ed., O Fim da URSS, a Nova Rússia e a crise das esquerdas, Lisboa: Colibri (2013b), p. 143-165.

DMITRIEV, Mikhail e TREISMAN, Daniel - The Other Russia: Discontent grows in the Hinterlands. Foreign Affairs. Vol. 91, N. ${ }^{\circ} 5$ (2012), p. 59-72.

Foreign Policy Concept of the Russian Federation. 12 julho 2008. [Acedido a 3 de jun. de 2011]. Disponível na Internet: http://www.mid.ru/nsosndoc.nsf/1e5f0de28fe 77 fdcc 325 75d900298676/869c9d2b87ad8014c32575d9002b1c38?OpenDocument

Frankfurter Allgemeine Zeitung, "Kreml kritisiert CDU-Politiker Schockenhoff", 14 agosto 2012. [Acedido a 12 de set. de 2012]. Disponível na Internet: http://www.faz.net/aktuell/politik/ ausland/prozess-gegen-pussy-riot-kreml-kritisiert-cdu-politiker-schockenhoff-11855427.html.

FREIRE, Maria Raquel e DAEHNHARDT, Patricia - As relações entre a Alemanha e a Rússia: Duas políticas externas em transição. Relações Internacionais. N. ${ }^{\circ} 32$ (2011), p. 171-196.

HOYER, Werner - Discurso no seminário "Strategic Seminar 3: NATO's Partnerships and Beyond", 14 janeiro 2010. [Acedido a 6 de jan. de 2012]. Disponível na Internet: http:// www.auswaertiges-amt.de/diplo/en/Infoservice/Presse/Reden/2010/100115-Hoyer-OsloNatoRus.html.

ISCHINGER, Wolfgang - Yes to Missile Defense, With Russia. The New York Times, 17 maio 2012. [Acedido a 22 de jul. de 2012]. Disponível na Internet: http://www.nytimes. com/2012/05/18/opinion/yes-to-missile-defense-with-russia.html?_r=1\&.

ISCHINGER, Wolfgang e WEISSER, Ulrich - Getting Russia Right. The New York Times, 9 junho 2010. [Acedido a 19 de nov. de 2011]. Disponível na Internet: http://www.nytimes. com/2010/06/10/opinion/10iht-edischinger.html.

KAGAN, Robert - New Europe, Old Russia. The Washington Post, 6 fevereiro 2008. [Acedido a 16 de set. de 2011]. Disponível na Internet: http://www.washingtonpost.com/wpdyn/ content/article/2008/02/05/AR2008020502879.html.

KARAGANOV, Sergei; TELTSCHIK, Horst e OLECHOWSKI, Andrzej - Hotel Europe: Guests and Permanent Partners, 29 dezembro 2011. [Acedido a 3 de jan. de 2012]. Disponível na Internet: http://eng.globalaffairs.ru/number/Hotel-Europe-Guests-and-PermanentPartners-15432.

KRAMER, David J. - Resetting U.S.-Russian Relations: It Takes Two. The Washington Quarterly. Vol. 33, N. ${ }^{\circ} 1$ (2010), p. 61-79.

KUCHINS, Andrew C. e ZEVELEV, Igor A. - Russian Foreign Policy: Continuity in Change. The Washington Quarterly. Vol. 35, N. ${ }^{\circ} 1$ (2012), p. 147-161.

KUNDNANI, Hans - Germany as a Geo-economic Power. The Washington Quarterly. Vol. $34,{ }^{\circ} 3$ (2011), p. 31-45. 
MAKARYCHEV, Andrey S - Russia and its 'New Security Architecture' in Europe: A Critical Examination of the concept. CEPS Working Document. N. ${ }^{\circ}$ 310, (2009b). [Acedido a 12 de jun. de 2011]. Disponível na Internet: http://www.ceps.be/book/russia-and-its-newsecurity-architecture-europe-critical-examination-concept.

MEDVEDEV, Discurso do presidente Dmitry Medvedev - Speech at Meeting with German Political, Parliamentary and Civic Leaders, 5 junho 2008, Berlim. [Acedido a 7 de out. de 2010]. Disponível na Internet: http://archive.kremlin.ru/eng/speeches/2008/06/05/2203_ type82912type82914type84779_202153.shtml.

Memorando de Meseberg (2010). [Acedido a 5 de jun. de 2011]. Disponível na Internet: http://www.russianmission.eu/sites/default/files/user/files/2010-06-05-mesebergmemorandum.pdf.

MEISTER, Stefan - An alienated partnership: German-Russian relations after Putin's return. The Finnish Institute of International Affairs. N. ${ }^{\circ}$ 105, 10 maio 2012. [Acedido a 12 de set. de 2012]. Disponível na Internet: www.fiia.fi/assets/publications/bp105.pdf.

NATO Bucharest Summit Declaration (2008). [Acedido a 4 de jun. de 2011]. Disponível na Internet: http://www.nato.int/cps/en/natolive/official_texts_8443.htm.

NATO 2020: Assured Security, Dynamic Engagement (2010) North Atlantic Treaty Organization. [Acedido a 4 de jun. de 2011]. Disponível na Internet: http://www.nato.int/nato_static/ assets/pdf/pdf_2010_05/20100517_100517_expertsreport.pdf.

Ost-Ausschuss der Deutschen Wirtschaft - Rekordergebnis für Exporte nach Osteuropa, 2 março 2012. [Acedido a 22 de jul. de 2012]. Disponível na Internet: http://www.ostausschuss.de/rekordergebnis-f-r-exporte-nach-osteuropa.

Ost-Ausschuss der Deutschen Wirtschaft - Wege zur Visa-Freiheit, novembro 2011, p. 5. [Acedido a 22 de jul. de 2012]. Disponível na Internet: http://www.ost-ausschuss.de/sites/default/ files/pm_pdf/Positionspapier\%20Wege\%20zur\%20Visa-Freiheit-Ost-Ausschuss_0.pdf.

PIPES, Richard - Russia under the Bolshevik Regime. London: Harper Collins, 1995.

SAKWA, Richard - Russia and Europe: Whose Society? European Integration. Vol. 33, N. 2 (2011), p. 197-214.

SIEVERT, Stephan; ZAKHAROV, Sergey e KLINGHOLZ, Reiner - The Waning World Power: The demographic future of Russia and the other Soviet successor states. Berlin Institut für Bevölkerung und Entwicklung, 2011. [Acedido a 16 de fev. de 2011]. Disponível na Internet: http://www.berlin-institut.org/fileadmin/user_upload/Russland/Russland_e_online.pdf.

SMITH, Keith - Russia-Europe Energy Relations Implications for U.S. Policy. CSIS, 2010. [Acedido a 8 de jun. de 2011]. Disponível na Internet: http://csis.org/files/publication/100218_ Smith_RussiaEuropeEnergy_Web.pdf.

Spiegel, Der - Open letter: It's Time to Invite Russia to Join NATO, 8 março 2010. [Acedido a 4 de jun. de 2011]. Disponível na Internet: http://www.spiegel.de/international/world/ open-letter-it-s-time-to-invite-russia-to-join-nato-a-682287.html.

Statistische Bundesamt, Destatis, Comunicado de imprensa no. 204, de 4 junho 2008. [Acedido a 3 de mar. de 2012]. Disponível na Internet: http://www.destatis.de/jetspeed/ portal/cms/Sites/destatis/Internet/DE/Presse/pm/2008/06/PD08__204_51.psml.

STEINMEIER, Frank-Walter - Russland, Europa und die Welt - Perspektiven der Zusammenarbeit in globalen Sicherheitsfragen. Discurso na $42^{a}$ Conferência de Segurança de Munique, 5 fevereiro 2006.

STELZENMÜLlER, Constanze - Germany's Russia Question. Foreign Affairs. Vol. 88, N. ${ }^{\circ} 2$ (2009), p. 89-100.

STENT, Angela - Russia and Germany Reborn: Unification, Soviet Collapse, and the New Europe. Princeton: Princeton University Press, 1999. 
SZABO, Stephen - Can Berlin and Washington Agree on Russia?. The Washington Quarterly. Vol. 32, N. ${ }^{\circ} 4$ (2009), p. 23-41.

TSYGANKOV, Andrei - Russia's foreign policy: change and continuity in national identity. Lanham: Rowman \& Littlefield, 2006.

TURKOWSKI, A. - The Polish-German Tandem. Carnegie Moscow Center - Carnegie Endowment for International Peace, 2011. [Acedido a 4 de jun. de 2011]. Disponível na Internet: http://carnegie.ru/publications/?fa $=46059$.

VINOCUR, John - Germany's 'unpolitical' new president. The New York Times, 26 março 2012. [Acedido a 23 de abr. de 2012]. Disponível na Internet: http://www.nytimes. com/2012/03/27/opinion/germanys-unpolitical-new-president.html?_r=0.

WESTPHAL, Kirsten - Das neue Öl? Worauf beim Gas jetzt zu achten ist. Stiftung Wissenschaft und Politik, 10 junho 2011. [Acedido a 16 de dez. de 2011]. Disponível na Internet: http://www.swp-berlin.org/de/kurz-gesagt/energiewende-und-gas.html.

World Bank (The) - Russia Overview. World Bank, 2013. [Acedido a 12 de mar. de 2013]. Disponível na Internet: http://www.worldbank.org/en/country/russia/overview. 
